\title{
MeningKatKan Kemampuan PeMECAHAN MaSAlah DAN Komunikasi Matematik Melalui Pendekatan Problem Posing DALAM PEMBELAJARAN MATEMATIKA Di SMA
}

\author{
Improving Mathematical Problem Solving AND Communication SKillS \\ THROUGH PROBLEM POSING APPROACH IN MATHEMATICAL LEARNING AT HIGH \\ SCHOOL
}

\author{
Deddy Sofyan ${ }^{1}$ dan Sukanto Sukandar Madio³ \\ 1 Pendidikan Matematika, STKIP Garut \\ deddysofyan1968@gmail.com \\ 2 Pendidikan Matematika, STKIP Garut \\ sukantosm@gmail.com
}

\begin{abstract}
Abstrak
Tujuan penelitian ini adalah untuk meningkatkan kemampuan siswa SMA dalam pemecahan masalah dan komunikasi matematik melalui pendekatan problem posing dalam pembelajaran matematika. Metode penelitian yang digunakan adalah metode kuasi eksperimen. Populasi penelitian ini adalah siswa di salah satu SMA Negeri di Kabupaten Garut. Sampel penelitian dipilih secara acak berdasarkan kelas, sampelnya adalah kelas XII IPA 1 yang mendapat pembelajaran menggunakan pendekatan problem posing dan siswa kelas XII IPA 3 yang mendapat pembelajaran konvensional. Simpulan hasil penelitian ini adalah bahwa dalam pembelajaran matematika di SMA: 1. Kemampuan pemecahan masalah matematik siswa yang mendapatkan pendekatan problem posing lebih baik dibandingkan dengan konvensional, 2 . Tidak terdapat perbedaan kemampuan komunikasi matematik antara siswa yang mendapatkan pendekatan problem posing dengan konvensional, 3. Tidak terdapat kaitan yang signifikan antara kemampuan pemecahan masalah matematik dengan kemampuan komunikasi matematik pada siswa yang mendapatkan pendekatan problem posing.

Kata Kunci: Problem Posing, Pemecahan Masalah, Komunikasi Matematika.
\end{abstract}

\begin{abstract}
The purpose of this research is to improve the ability of high school students in problem solving and communication of mathematics through problem posing approach to learning mathematics. The method used is a quasi-experimental method. The study population was one of the students in high schools in Garut. Samples were selected randomly based on the class, the sample is a class XII IPA 1 gets learning using problem posing approach and class XII IPA 3 students who received conventional learning. Conclusion The results of this study is that the study of mathematics in high school: 1. mathematical problem solving ability of students to get a better problem posing approach compared to conventional, 2. there is no difference in the ability of mathematical communication between students who received conventional approach to problem posing, 3 . there was no significant association between mathematical problem solving skills with communication skills in students who get a mathematical problem posing approach. Keyword: Problem Posing, Problem Solving, Communication Mathematics.
\end{abstract}




\section{Pendahuluan}

Kadir (2010) menyatakan bahwa dalam pemecahan masalah matematika terbentuk juga kemampuan matematika lainnya seperti penalaran dan bukti, koneksi matematik, komunikasi matematik, dan representasi matematik. Dalam aktivitas siswa mengkomunikasikan ide-ide matematikanya ketika memecahkan masalah atau ketika menyampaikan proses dan hasil pemecahan masalah merupakan kemampuan yang dapat mengembangkan kemampuan berpikir matematik tingkat tinggi siswa seperti logis, analitis, sistematis, kritis, kreatif, dan produktif. Hal ini menunjukkan bahwa betapa pentingnya kemampuan pemecahan masalah dan komunikasi matematik dalam pembelajaran matematika.

Nilai UN siswa SMA/MA Kabupaten Garut untuk mata pelajaran matematika pada tahun pelajaran 2012/2013 adalah 5,96 , nilai tersebut menggambarkan bahwa untuk mata pelajaran matematika, prestasi belajar siswa SMA/MA Kabupaten Garut masih rendah. Kenyataan tersebut mengharuskan adanya upaya untuk meningkatkan kualitas pendidikan di Kabupaten Garut, khususnya dalam mata pelajaran matematika. Salah satu upaya yang dapat dilakukan dalam menyikapinya adalah pemilihan model pembelajaran yang tepat.
Salah satu pendekatan pembelajaran yang dinilai dapat meningkatkan kemampuan pemecahan masalah dan kemampuan komunikasi matematik adalah Pendekatan Problem Posing. Torp dan Sage (Lin dan Huang, 2007), menyatakan bahwa pembelajaran yang berdasarkan masalah (problem) berpusat pada siswa (student centered), dan melibatkan kemampuan berpikir tingkat tinggi.

Rumusan masalah dalam penelitian adalah sebagai berikut:

1. Kemampuan komunikasi manakah yang lebih baik yang dicapai siswa yang mengikuti pembelajaran dengan Pendekatan Problem Posing dan Konvensional

2. Kemampuan pemecahan masalah manakah yang lebih baik yang dicapai siswa yang mengikuti pembelajaran dengan Pendekatan Problem Posing dan Konvensional.

Apakah terdapat kaitan antara kemampuan pemecahan masalah dan kemampuan komunikasi matematik siswa yang mengikuti pembelajaran dengan Pendekatan Problem Posing.

Tujuan penelitian dalam penelitian ini adalah:

1. Menelaah pembelajaran yang lebih baik dalam meningkatkan kemampuan komunikasi matematik siswa SMA.

2. Menelaah pembelajaran yang lebih baik dalam meningkatkan 
kemampuan pemecahan masalah

matematik siswa SMA.

Untuk mengetahui apakah terdapat kaitan antara kemampuan pemecahan masalah dan kemampuan komunikasi matematik siswa SMA.

Manfaat penelitian ini adalah:

1. Bagi guru, bahan ajar dan panduan ajar dalam pembelajaran matematika dengan menggunakan pendekatan problem posing diharapkan memberi gambaran tentang bagaimana menerapkan pendekatan Problem Posing dan kaitannya dengan peningkatan kemampuan pemecahan masalah dan komunikasi matematik siswa.

2. Bagi siswa, dapat menumbuhkembangkan kemampuan pemecahan masalah dan komunikasi matematik.

Bagi peneliti, dapat menjadi bahan referensi bagi penelitian selanjutnya.

Hipotesis penelitian ini adalah:

1. Kemampuan komunikasi matematik siswa yang mendapatkan pendekatan Problem Posing lebih baik dari siswa dengan pembelajaran konvensional.

2. Kemampuan pemecahan masalah matematik siswa yang mendapatkan pendekatan Problem Posing lebih baik dari siswa dengan pembelajaran konvensional.

Terdapat kaitan antara kemampuan pemecahan masalah dan kemampuan komunikasi matematik siswa yang mendapatkan pendekatan Problem Posing.
Beberapa istilah, definisi operasional yang digunakan dalam penelitian ini adalah sebagai berikut:

Pendekatan Problem Posing adalah pembelajaran dengan tahapan sebagai berikut:

1. Membuat Situasi Matematik (Creating Mathematics Situations).

2. Pengajuan Masalah Matematik (Posing Mathematics Problem)

3. Menyelesaikan Masalah Matematik (Solving Mathematics Problem)

Penerapan Matematika (Applying

Mathematics)

Kemampuan Pemecahan Masalah Matematik adalah:

Kemampuan memahami masalah, merencanakan strategi dan prosedur pemecahan masalah, melakukan prosedur pemecahan masalah, memeriksa kebenaran jawaban dan hasil yang diperoleh serta menuliskan jawaban akhir sesuai dengan permintaan soal.

Kemampuan Komunikasi Matematik adalah kemampuan meliputi:

1. Mengekspresikan, mendemonstrasikan dan melukiskan ide-ide matematik ke dalam bentuk gambar, tabel, grafik atau model matematik lain.

2. Menyatakan gambar atau diagram ke dalam ide-ide matematik.

Stanic \& Kilpatrick (Herman, 2006) menyatakan tiga peranan pokok pemecahan masalah dalam pembelajaran matematika di sekolah, yaitu pemecahan masalah sebagai konteks, pemecahan masalah sebagai keterampilan, dan 
pemecahan masalah sebagai seni. Ketika pemecahan masalah digunakan sebagai konteks dalam matematika, penekanannya adalah agar siswa tertarik dan aktif melibatkan diri dalam menyelesaikan tugas atau problem yang membantu menjelaskan prosedur atau konsep matematika. Ketika pemecahan masalah digunakan sebagai keterampilan, maka aktivitas pemecahan masalah bukan sebagai suatu keterampilan yang terpisah namun harus dijadikan aktivitas pengembangan memahami konsep dan keterampilan dasar. Ketika pemecahan masalah digunakan sebagai seni, maka pemecahan masalah dapat dipandang sebagai seni dari inkuiri dan seni penemuan. Dengan demikian, pemecahan masalah sebagai seni adalah mengembangkan kemampuan siswa sehingga menjadi problem solver yang terampil dan bersemangat, menjadi pemikir yang independen dalam menyelesaikan masalah-masalah terbuka.

Kaitan antara komunikasi dan pemecahan masalah dalam pembelajaran matematika menurut Scheider dan Saunders (Hulukati, 2005) adalah komunikasi dalam pembelajaran matematika bertujuan untuk membantu siswa dalam memahami soal cerita dan mengkomunikasikan hasilnya. Selain itu penguasaan bahasa yang baik mampu membantu pemahaman dan idea matematika siswa. Kemampuan siswa dalam mengkomunikasikan masalah matematik, pada umumnya ditunjang oleh pemahaman mereka terhadap bahasa (Lubienski, 2000).

Tanpa komunikasi dalam matematika kita akan memiliki sedikit keterangan, data, dan fakta tentang pemahaman siswa dalam melakukan proses dan aplikasi matematika. Karena itu, komunikasi dalam matematika dapat membantu siswa menginterpretasikan dan mengekspresikan pemahamannya tentang konsep dan proses matematika yang dipelajari. Menurut NCTM (2000) melalui komunikasi diharapkan siswa dapat menata dan menggabungkan pemikiran matematika, mengkomunikasikan pemikiran matematika kepada teman sebaya, guru atau yang lainnya, menggunakan bahasa matematika untuk mengekspresikan ide-ide secara tepat.

Silver et. Al., (1996) dalam penelitiannya menemukan bahwa pendekatan pengajuan masalah matematik merupakan aktivitas dengan dua pengertian yang berbeda, yaitu: proses mengembangkan masalah matematik yang baru oleh siswa berdasarkan situasi yang ada dan proses memformulasikan kembali masalah matematik dengan kata-kata sendiri berdasarkan situasi yang diberikan. Dengan demikian, masalah matematik yang diajukan oleh siswa mengacu pada situasi yang disiapkan oleh guru. 
Pengajuan masalah matematik menurut Brown dan Walter (1990) terdiri dari 2 aspek penting, yaitu accepting dan challenging. Accepting berkaitan dengan kemampuan siswa memahami situasi yang diberikan oleh guru atau situasi yang sudah ditentukan. Sementara challenging, berkaitan dengan sejauhmana siswa merasa tertantang dari situasi yang diberikan sehingga melahirkan kemampuan mengajukan masalah atau soal matematika. Hal ini berarti bahwa pengajuan masalah matematika dapat membantu siswa untuk mengembangkan proses nalar mereka.

Pengertian problem posing tidak terbatas pada pengajuan masalah yang betul-betul baru, tetapi dapat berarti mereformulasi soal-soal yang diberikan. Terdapat beberapa cara pembentukan soal baru dari soal yang diberikan, misalnya dengan mengubah atau menambah data atau informasi pada soal itu, misalnya mengubah bilangan, operasi, objek, syarat, atau konteksnya. Hal itu sesuai dengan pengertian problem posing yang dikemukakan Silver (Lin, 2004). Ia mendefinisikan problem posing sebagai pembuatan soal baru oleh siswa berdasarkan soal yang telah diselesaikan.

Menurut Silver (Abu-Elwan, 2000), problem posing meliputi beberapa pengertian, yaitu (1) perumusan soal atau perumusan ulang soal yang telah diberikan dengan beberapa perubahan agar lebih mudah dipahami siswa, (2) perumusan soal yang berkaitan dengan syarat-syarat pada soal yang telah diselesaikan dalam rangka penemuan alternatif penyelesaian, dan (3) pembuatan soal dari suatu situasi yang diberikan. Dari pandangan di atas, maka dapat dikatakan bahwa pengajuan masalah matematika merupakan reaksi terhadap situasi yang telah disediakan oleh guru. Reaksi tersebut berupa respon dalam bentuk pernyataan, pertanyaan non-matematika atau pertanyaan matematika, terlepas dari apakah pertanyaan matematika tersebut pada akhirnya dapat dipecahkan atau tidak. Pertanyaan matematika tersebut mungkin berkaitan dengan situasi yang diberikan atau merupakan pengembangan dari situasi lain. Dengan demikian, terdapat 3 unsur penting yang saling terkait dalam pembelajaran dengan pendekatan pengajuan masalah matematika, yaitu (1) situasi masalah, (2) pengajuan masalah dan (3) pemecahan masalah (Hamzah dalam Nurjanah, 2009).

Menurut Nurjanah (2009), keterkaitan antara kemampuan pemecahan masalah dan kemampuan pengajuan masalah dapat dijelaskan sebagai berikut. Ketika siswa membuat soal, siswa dituntut untuk memahami soal dengan baik. Hal ini merupakan tahap pertama dalam penyelesaian masalah. Mengingat soal yang dibuat siswa juga harus diselesaikan, tentu siswa berusaha untuk dapat membuat perencanaan penyelesaian berupa pembuatan model matematika untuk kemudian menyelesaikannya. Hal ini juga merupakan tahapan penyelesaian masalah seperti dikemukakan Polya di atas. 
Berdasarkan penelitian terkini, menurut Winograd (Lin, 2004), pemberian tugas kepada siswa untuk mengajukan masalah dapat meningkatkan kemampuan siswa memecahkan masalah dan sikap mereka terhadap matematika. Menurut English (Christou et al, 1999), problem posing dapat meningkatkan kemampuan berpikir, kemampuan memecahkan masalah, sikap serta kepercayaan diri siswa dalam menyelesaikan masalah dan secara umum berkontribusi terhadap pemahaman konsep matematika. Hal itu juga diperkuat Killpatrik (Christou et al, 1999) yang mengatakan bahwa kualitas pertanyaan atau soal yang dibuat siswa menggambarkan kemampuan siswa menyelesaikan masalah. Berdasarkan penelitiannya Silver dan Cai sebagaimana dikutip Christou et al (1999) menyimpulkan adanya hubungan yang kuat antara problem posing dan problem solving. la menggunakan problem posing sebagai alat untuk mempelajari proses kognitif dan menyatakan bahwa problem posing dapat digunakan untuk mengidentifikasi pengetahuan, penalaran, dan perkembangan konseptual siswa.

Keterkaitan pengajuan masalah dan pemecahan masalah diungkapkan oleh English (1997). Menurutnya, dengan membuat soal berarti tahap awal dalam memecahkan masalah, yaitu memahami soal telah terlewati, sehingga untuk menyelesaikan soal dengan tahap berikutnya akan terbuka. Sementara itu Silver dan Cai (1996) dalam penelitiannya menyebutkan bahwa kemampuan pengajuan masalah berkorelasi positif dengan kemampuan pemecahan masalah. Sedangkan English (1997) menjelaskan bahwa pembuatan soal dapat membantu siswa dalam mengembangkan keyakinan dan kesukaan terhadap matematika, sebab ide-ide matematika siswa dicobakan untuk memahami masalah yang sedang dikerjakan dan dapat menguatkan performannya dalam pemecahan masalah.

Sriraman, Pantazi, dan Pittalis (2005), menyatakan beberapa hasil penelitian dan pendapat mengenai penerapan pembelajaran Problem posing, yaitu sebagai berikut:

1. Kilpatrick (1987) menyatakan bahwa kualitas masalah yang diajukan siswa menggambarkan kemampuan siswa dalam menyelesaikan masalah.

2. Cai (1998) menyatakan kuatnya hubungan antara problem posing dan problem solving.

Silver (1995) mengklasifikasikan problem posing dengan mempertimbangkan apakah dilakukan sebelum, selama, atau setelah problem solving. Sebelum problem solving, masalah dihasilkan dari cerita, gambar, diagram, representasi; selama problem solving ketika siswa sengaja mengubah masalahnya menjadi lebih sederhana; setelah problem solving ketika 
pengalaman dalam konteks pemecahan masalah diterapkan dalam situasi baru.

\section{Metode}

Dalam penelitian ini perlakuannya sebagai berikut :

1). Ada dua kelompok siswa, yaitu kelompok yang pembelajarannya menggunakan pendekatan Problem Posing dan Pembelajaran Konvensional.

2). Untuk mengetahui kemampuan pemecahan masalah matematika dan komunikasi matematika siswa, maka siswa diberikan tes akhir.

Berdasarkan uraian di atas, desain penelitiannya adalah disain kelompok kontrol hanya postes (Ruseffendi, 1998):

A $\times O$

A

Subyek populasi penelitian ini adalah siswa SMA Negeri kategori sekolah kelompok sedang di Kabupaten Garut. Adapun yang menjadi subyek populasi dalam penelitian ini adalah siswa di salah satu SMA Negeri di kabupaten Garut. Sampel penelitian ini adalah siswa kelas XII IPA 1 sebagai kelas eksperimen dan XII IPA 3 sebagai kelas kontrol. Pemilihan sampel dilakukan secara acak, tanpa mengubah kelas yang ada. Pelaksanaan penelitian di kelas eksperimen dan kontrol dimulai tanpa tes awal, karena materi yang diajarkan merupakan materi yang baru yang diajarkan di kelas XII. Pelaksanakan pembelajaran di kelas eksperimen dan kontrol dilakukan untuk satu standar kompetensi, yaitu sebanyak 10 jam pelajaran, 8 jam pelajaran untuk tatap muka, dan 2 jam pelajaran untuk tes akhir. Penelitian ini dilaksanakan dari tanggal 12 Agustus 2016 sampai dengan 26 September 2016.

Penelitian ini melibatkan dua jenis variabel: variabel bebas, yaitu pendekatan Problem Posing serta pembelajaran konvensional; variabel terikat, yaitu kemampuan pemecahan masalah matematik dan kemampuan komunikasi matematik siswa. Penelitian ini menggunakan jenis instrumen tes. Instrumen jenis tes adalah instrumen kemampuan pemecahan masalah matematika dan kemampuan komunikasi matematik.

Analisis data hasil tes kemampuan pemecahan masalah matematika dan kemampuan komunikasi matematik siswa dilakukan secara kuantitatif. Uji statistik yang akan digunakan berdasarkan pemilihan uji statistik seperti pada Tabel berikut:

Tabel 1.

Pemilihan Uji Statistik Univariat/Bivariat

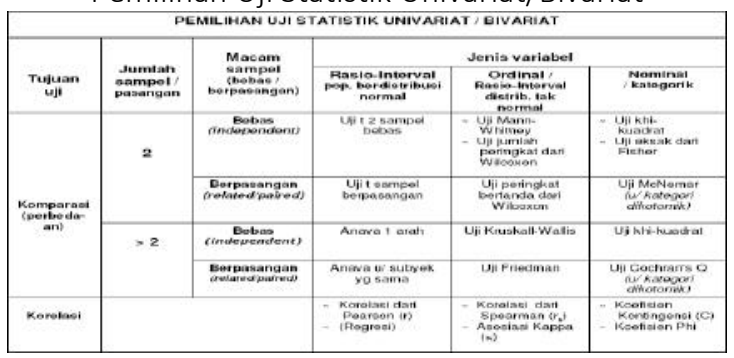

\section{Hasil dan Pembahasan}

A. Hasil Penelitian

Tabel 2.

Statistik Deskriptif Skor Tes akhir Kelas Eksperimen dan Kontrol 


\begin{tabular}{|c|c|c|c|c|c|c|c|c|c|c|c|c|}
\hline \multirow[t]{2}{*}{ Kelas } & \multirow{2}{*}{$\begin{array}{l}\text { Skor } \\
\text { Ideal }\end{array}$} & \multicolumn{5}{|c|}{ Kemampuan Pemecahan Masalah } & \multirow{2}{*}{$\begin{array}{l}\text { Skor } \\
\text { Ideal }\end{array}$} & \multicolumn{5}{|c|}{ Kemampuan Komunikasi Matematik } \\
\hline & & $x_{\min }$ & $x_{\text {maks }}$ & $\bar{x}$ & $\%$ & $\mathrm{~s}$ & & $x_{\min }$ & $x_{\text {maks }}$ & $\bar{x}$ & $\%$ & s \\
\hline Eksp. & 8 & 1 & 8 & 3,66 & $\begin{array}{l}45,7 \\
5\end{array}$ & 2,10 & 8 & 2 & 8 & 3,45 & 43,13 & 2,90 \\
\hline Kontrol & 8 & 0 & 6 & 2,44 & 30,5 & 1,25 & 8 & 0 & 8 & 3,69 & 46,13 & 1,92 \\
\hline
\end{tabular}

\section{B. Perbedaan Kemampuan Pemecahan Masalah Matematik Siswa Kelas Eksperimen dan Kelas Kontrol}

Untuk melihat apakah kemampuan pemecahan masalah matematik antara kelas eksperimen dan kelas kontrol berbeda atau tidak secara signifikan, dilakukan analisis statistik pengujian perbedaan rerata dua sampel yang independen, namun terlebih dahulu dilakukan uji normalitas. Dalam penelitian ini, untuk analisis statistik penulis mengggunakan program SPSS versi 16.0.

Uji normalitas yang penulis gunakan adalah uji Kolmogorof-Smirnov, dengan kriteria : jika nilai Sig $(p)>\alpha$, maka sebaran data berdistribusi normal. Taraf signifikan pada pengujian ini adalah 0,05. Hasil uji normalitas terhadap nilai tes akhir kemampuan pemecahan masalah matematik kelas eksperimen dan kelas kontrol dapat dilihat pada Tabel berikut.

Tabel 3.

Hasil Uji Normalitas Nilai Tes Akhir Kemampuan

Pemecahan Masalah Kelas Eksperimen dan Kelas Kontrol

\begin{tabular}{lllll|}
\hline Kelas & $\begin{array}{l}\text { Kolmogorov } \\
\text {-Smirnov Z }\end{array}$ & $\begin{array}{l}\text { Asym } \\
\text { p. Sig. }\end{array}$ & $\alpha$ & $\begin{array}{l}\text { Kesimpu } \\
\text { lan }\end{array}$ \\
\hline $\begin{array}{l}\text { Eksperi } \\
\text { men }\end{array}$ & 0,281 & 0,000 & 0,05 & $\begin{array}{l}\text { Tidak } \\
\text { Normal }\end{array}$ \\
\hline Kontrol & 0,482 & 0,000 & 0,05 & $\begin{array}{l}\text { Tidak } \\
\text { Normal }\end{array}$ \\
\hline
\end{tabular}

Untuk mengetahui adanya perbedaan atau tidak mengenai nilai tes akhir kemampuan pemecahan masalah matematik antara kelas eksperimen dan kelas kontrol digunakan uji statistik non parametrik dalam hal ini uji U Mann Whitney. Kriteria pengujian $H_{0}$ adalah: terima $H_{0}$ jika Sig $(p)>\alpha$. Hasil Uji $U$ Mann Whitney untuk nilai tes akhir kemampuan pemecahan masalah eksperimen dan kelas kontrol dapat dilihat pada Tabel 4.

Tabel 4.

Hasil Uji Mann Whitney Nilai Tes Akhir Kemampuan Pemecahan Masalah Kelas Eksperimen dan Kelas Kontrol

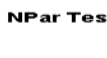

[Dataseto]

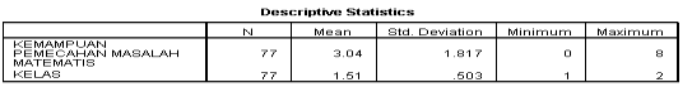

Mann-whitney
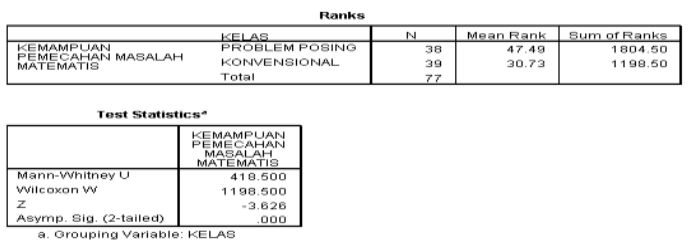

Taraf signifikan pada pengujian ini adalah 0,05. Dari Tabel 4, nilai Asymp.Sig. $=0,000<\alpha=0,05$, karenanya tolak $H_{0}$. 
Tidak terdapat perbedaan yang signifikan peningkatan kemampuan pemecahan masalah matematik antara kelas eksperimen dan kelas kontrol. Sehingga dapat disimpulkan bahwa terdapat perbedaan yang signifikan kemampuan pemecahan masalah matematik antara kelas eksperimen dan kelas kontrol. Dilihat dari rerata nilai tes akhir, kemampuan pemecahan masalah matematik siswa kelas eksperimen lebih baik dari kelas kontrol.

\section{Perbedaan Kemampuan Komunikasi Matematik Siswa Kelas Eksperimen dan Kelas Kontrol}

Tabel 5.

Hasil Uji Normalitas Nilai Tes Akhir Kemampuan Komunikasi Matematik Kelas Eksperimen dan Kelas Kontrol

\begin{tabular}{lllll|}
\hline Kelas & $\begin{array}{l}\text { Kolmogorov } \\
\text {-Smirnov Z }\end{array}$ & $\begin{array}{l}\text { Asym } \\
\text { p.Sig. }\end{array}$ & $\alpha$ & $\begin{array}{l}\text { Kesimpu } \\
\text { lan }\end{array}$ \\
\hline $\begin{array}{l}\text { Eksperi } \\
\text { men }\end{array}$ & 0,377 & 0,000 & 0,05 & $\begin{array}{l}\text { Tidak } \\
\text { Normal }\end{array}$ \\
\hline Kontrol & 0,221 & 0,000 & 0,05 & $\begin{array}{l}\text { Tidak } \\
\text { Normal }\end{array}$ \\
\hline
\end{tabular}

Untuk mengetahui adanya perbedaan atau tidak mengenai nilai kemampuan komunikasi matematik antara kelas eksperimen dan kelas kontrol digunakan uji statistik non parametrik dalam hal ini uji U Mann Whitney. Kriteria pengujian $H_{0}$ adalah: terima $H_{0}$ jika Sig $(\mathrm{p})>\alpha$. Hasil Uji U Mann Whitney untuk nilai tes akhir kemampuan komunikasi matematik kelas eksperimen dan kelas kontrol dapat dilihat pada Tabel 6 .

Tabel 6.
Hasil Uji Mann Whitney Nilai Tes Akhir Kemampuan Komunikasi Matematik Kelas Eksperimen dan Kelas Kontrol

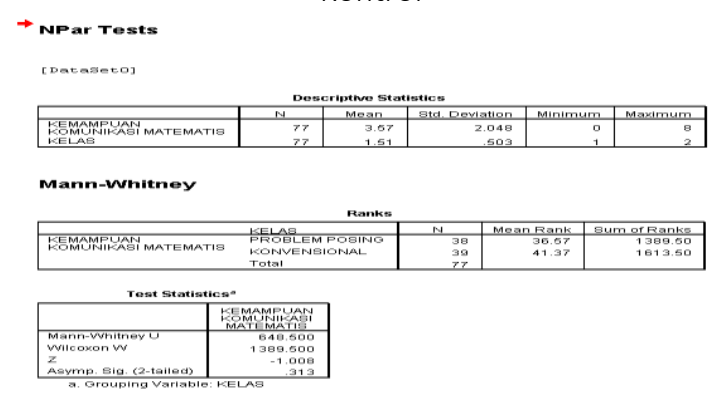

Taraf signifikan pada pengujian ini adalah 0,05. Dari Tabel 6, nilai Asymp.Sig. $=0,313>\alpha=0,05$, karenanya terima $H_{0}$. Tidak terdapat perbedaan yang signifikan peningkatan kemampuan komunikasi matematik antara kelas eksperimen dan kelas kontrol. Sehingga dapat disimpulkan bahwa tidak terdapat perbedaan yang signifikan kemampuan komunikasi matematik antara kelas eksperimen dan kelas kontrol.

\section{Kaitan antara Pemecahan Masalah Matematik dan Kemampuan Komunikasi Matematik Siswa Kelas Eksperimen}

Untuk melihat kaitan apakah siswa yang mempunyai kemampuan komunikasi matematik dengan kategori tinggi akan mempunyai kemampuan pemecahan masalah matematik dengan kategori tinggi juga, dalam penelitian ini digunakan asosiasi kontengensi. Data yang diasosiasikan adalah kategori kemampuan komunikasi matematik dan pemecahan masalah matematik. Perhitungan koefisien kontengensi menggunakan SPSS versi 16.0. 
Pada kelas eksperimen, asosiasi kontingensi antara kemampuan komunikasi matematik dan pemecahan masalah matematik adalah seperti pada tabel 7 berikut:

Tabel 7.

Asosiasi Kontingensi antara Kemampuan Komunikasi Matematik dan Pemecahan Masalah Matematik Kelas Eksperimen

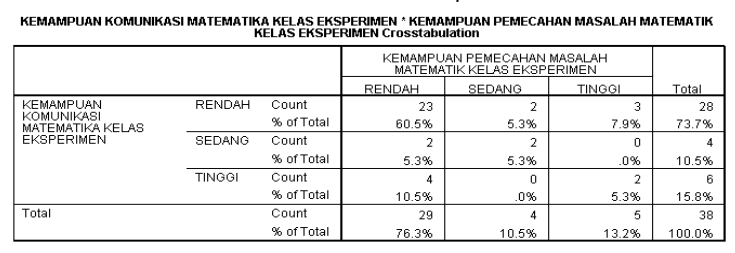

Tabel 8.

Korelasi Berdasarkan Kategori Kemampuan Komunikasi Matematik dan Pemecahan Masalah Kelas Eksperimen

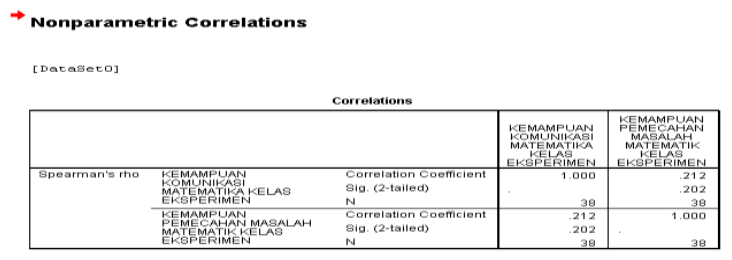

Dari Tabel 8 didapat besar korelasi dari Spearman adalah sebesar 0,212, dengan Sig. $=0,202$. Karena Sig. $=0,202>\alpha=0,05$, maka berarti pada kelas eksperimen, tidak terdapat kaitan yang signifikan berdasarkan kategori antara kemampuan pemecahan masalah dan kemampuan komunikasi matematik.

\section{E. Pembahasan}

Berdasarkan hasil penelitian, diperoleh hasil penelitian bahwa dalam pembelajaran matematika di SMA: 1). 102
Kemampuan pemecahan masalah matematik siswa yang mendapatkan pendekatan problem posing lebih baik dibandingkan dengan konvensional. 2). Tidak terdapat perbedaan kemampuan Komunikasi matematika antara siswa yang mendapatkan pendekatan problem posing dengan konvensional dalam pembelajaran matematika. 3). Tidak terdapat kaitan antara pemecahan masalah matematik dan kemampuan komunikasi matematik.

Beberapa temuan dari data hasil penelitian adalah sebagai berikut:

1. Kemampuan pemecahan masalah matematik siswa yang mendapatkan pendekatan problem posing lebih baik dibandingkan konvensional.

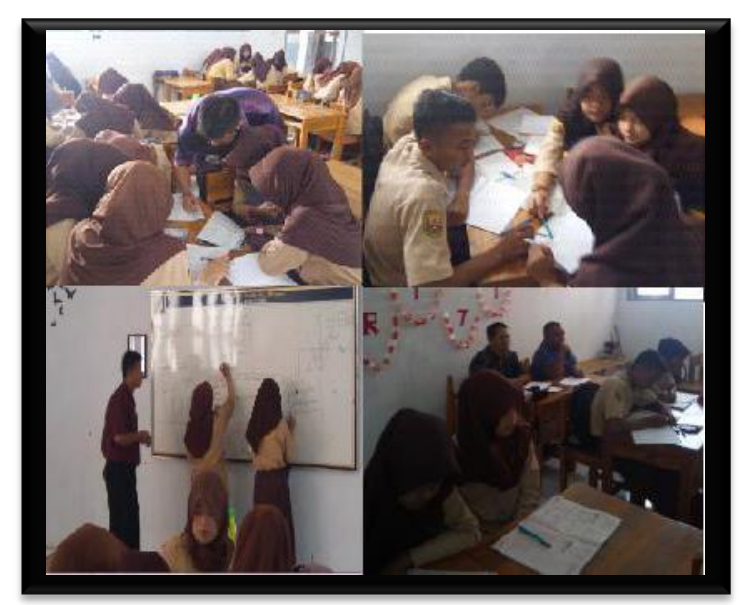

Gambar 1. Aktivitas Siswa di Kelas Eksperimen.

2. Masih terdapat sebagian besar siswa yaitu sebanyak 23 orang $(60,5 \%)$ yang memiliki kemampuan komunikasi matematik dan kemampuan pemecahan masalah matematik dengan kategori rendah. Dan hanya Jurnal "Mosharafa", Volume 6, Nomor 1, Januari 2017 
sebagian kecil siswa yaitu 2 orang (5,3\%) yang memiliki kemampuan komunikasi matematik dan kemampuan pemecahan masalah matematik dengan kategori tinggi.

\section{Penutup}

Simpulan hasil penelitian ini adalah bahwa dalam pembelajaran matematik di SMA:

1. Kemampuan pemecahan masalah matematik siswa yang mendapatkan pendekatan problem posing lebih baik dibandingkan dengan konvensional.

2. Tidak terdapat perbedaan kemampuan komunikasi matematik antara siswa yang mendapatkan pendekatan problem posing dengan konvensional.

3. Tidak terdapat kaitan yang signifikan antara kemampuan pemecahan masalah matematik dengan kemampuan komunikasi matematik pada siswa yang mendapatkan pendekatan problem posing.

\section{Daftar Pustaka}

Abu-Elwan, R. (2000). Effectiveness of Problem Posing Strategies on Perspective Mathematics Teachers' Problem Solving Performance. [Online] Tersedia http://math.unipa.it/ grim/AAbuElwa n1-6. [7 September 2007].

Brown, S., \& Walter, M. I. (1990). The Art of Problem Posing. Philadelphia, PA: Franklin Institute Press.
English, L. D. (1997). Promoting a Problemposing Classroom, Teaching Children Mathematics, 3, pp. 172-179.

Herman, T. (2006). Pembelajaran Berbasis Masalah untuk Meningkatkan Kemampuan Berpikir Matematika Tingkat Tinggi Siswa Sekolah Menengah Pertama (SMP). Disertasi pada PPS Universitas Pendidikan Indonesia, Bandung: Tidak Diterbitkan.

Hulukati, E. (2005). Mengembangkan Kemampuan Komunikasi dan Pemecahan Masalah Matematika Siswa SMP melalui Model Pembelajaran Generatif.. Disertasi pada PPS Universitas Pendidikan Indonesia, Bandung: Tidak Diterbitkan.

Kadir (2010). Penerapan Pembelajaran Kontekstual Berbasis Potensi Pesisir Sebagai upaya Peningkatan kemampuan Pemecahan Masalah Matematika, Komunikasi Matematika, dan Keterampilan Sosial Siswa SMP. Disertasi. Bandung: SPS UPI.

Lin, P.J. (2004). Suporting Teachers On Designing Problem-Posing Task As A Tool Of Assessment To Understand Students' Mathematical Learning. Proceedings of the 28th Conference of the International Group for the Psychology of Mathematics Education, 2004 Vol 3 pp 257-264 Taiwan: National Hsin-Chu Teachers College.

Lin,C., Huang, H. (2007). The Comparison of Problem-based Learning (PmBL) 
Model and Project-based Learning (PtBL) Model. International Conference on Engineering Education - ICEE 2007 (September 3 - 7, 2007). http://www.ineer.org/Events/ICEE200 7/papers/179.pdf. [online]. Tersedia. 9-9-2010.

Lubienski, S.T. (2000). Problem Solving as Means Towards Mathematics for All: An Exploratory Llok Through a Class lens. Journal for Research in Mathematics Education. 31 94), 454482.

NCTM - National Council of Teachers of Mathematics (2000). Principles and standards for school mathematics. Reston, VA: NCTM.

Nurjanah (2009). Problem Posing Approach in Mathematics In Acceleration Class At SMAN 1 Sumedang Through Lesson Study. Disajikan pada the $2^{\text {nd }}$ International Conference on Lesson Study (ICLS). UPI: FPMIPA

Ruseffendi, E.T. (1998). Dasar-dasar Penelitian Pendidikan dan Bidang Non-Eksakta Lainnya. Semarang: IKIP Semarang Press.

Silver, E.A., Mamona-Downs, J., Leung. S.S., \& Kenny, P.A. (1996). Posing Mathematical Problems In A Complex Task Environment: An Exploratory Study. Journal For Research In Matematics Education, 27 (3), 293309.
Silver, E. A. \& Cai, J. (1996). An analysis of arithmetic problem posing by middle school students. Journal for Research in Mathematics Education, Vol27(5), pp.521-539.

Sriraman, Pantazi, dan Pittalis, et.al (2005). An Empirical Taxonomy of Problem Posing Processes. ZDM 2005 Vol. 37 (3). Cyprus: Departement of Education University of Cyprus.www.umt.edu/math/reports/s riraman/Int reviews Preprint Cyprus Sriraman.pdf. online. 20 juni 2011.

\section{Riwayat Hidup PenUlis \\ Drs. Deddy Sofyan, M.Pd..}

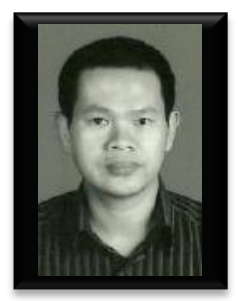

Staf pengajar di STKIP Garut. Studi S1 Pendidikan Matematika Universitas Pendidikan Indonesia, Bandung; S2 Pendidikan Matematika Universitas Pendidikan Matematika, Bandung; dan S3 Pendidikan Matematika Universitas Pendidikan Matematika, Bandung, sampai dengan sekarang.

Drs. Sukanto Sukandar Madio, M.Pd.

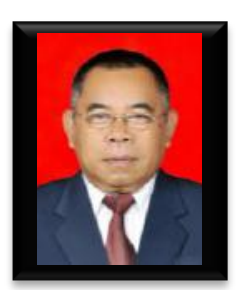

Staf pengajar di STKIP Garut. Studi S1 Pendidikan Matematika Universitas Pendidikan Indonesia, Bandung; S2 Pendidikan Matematika Universitas Pendidikan Matematika, Bandung. 